zasady tsinnisno-smyslovoi hotovnosti maibutnoho pedahoha do profesiinoi diialnosti [Theoretical and methodical foundations of future teachers' value-based readiness to professional activities]. Kyiv, 36 p. [in Ukrainian].

5. Polozenko, O. V. (2014). Model formuvannia psykholohichnoi hotovnosti maibutnikh fakhivtsiv ahrarnoi haluzi do profesiinoi diialnosti [Model of forming future agrarian readiness to professional activities]. Problems of modern pedagogic education. Series: pedagogy, psychology. Yalta: RYO KHU Publ., vol. 46., part. 4., pp. 213-220. [in Ukrainian].

6. Shvets, D. V. (2016). Pidhotovka maibutnikh ofitseriv MVS Ukrainy do okhorony i zabezpechennia hromadskoho poriadku v protsesi fakhovoi pidhotovky [Professional training of future officers of MIA of Ukraine to protection of public order and security]: Candidate's thesis. Kyiv, 225 p. [in Ukrainian].

Стаття надійшла до редакції 12.03.2018

УДК 371(09)(477.8)

DOI:

Леся Бодак, аспірант кафедри загальної педагогіки та дошкільної освіти Дрогобицького державного педагогічного університету імені Івана Франка

\title{
ОСТАП МАКАРУШКА ПРО ВПЛИВ ВІЙНИ НА ВИХОВАННЯ ДИТИНИ
}

У статті розкрито погляди О. Макарушки на соціальні, психологічні та педагогічні аспекти впливу війни та військових дій на формування підростаючого покоління. 3 'ясовано, щэо війна спричиняє переоиінку цінностей. Вивчено вплив війни на суспільство, молодь, на формування дисциплінованості, співчуття, справедливості, патріотизму, національної ідентичності, релігійності. Розкрито негативні наслідки впливу війни на молодь, виокремлено завдання вчителя та школи щэодо формування позитивних рис характеру молоді. Надано оцінку війні як антигуманному способу розв 'язання проблем. Розкрито роль учителів та школи у вихованні учнів у післявоєнний час.

Ключові слова: війна; виховання; учні; школа; цзіності виховання; формування характеру; О. Макарушка.

Лim. 6.

Lesya Bodak, Postgraduate Student of the General Pedagogy and Preschool Education Department Drohobych Ivan Franko State Pedagogical University

\section{OSTAP MAKARUSHKA ABOUT THE IMPACT OF WAR ON THE CHILD HEALTH}

The article reveals the views of Ostap Makarushka on the social, psychological and pedagogical aspects impact of the war and military actions on the formation of the young generation. The war influence on society, youth, on the formation of discipline, compassion, justice, patriotism, national identity, religiosity is studied. The negative effects of the war on young people (discord, cynical disrespect for someone else's property, humiliation of human dignity, alcoholism, gross sexual abuse, abuse over religious shrines, etc.) are revealed. The emphasis is on the fact that the young man must be prepared to perform warily obedience, to endure hunger during the few days, thirst, fatigue, insomnia, wounds, injuries, operations, family tortures, caring of relatives, women, children, sadness because of deceased comrades-companies. It is discovered that the war affects the education of discipline, increase and exacerbation of religious feelings, awareness of national identity. The teacher on military examples should form a feeling of compassion, empathy, sensitivity, kindness in the students. Humility, lies, and the merciless hatred of young people are at the same time ruining the foundations of Christian faith and human ethics. It is necessary to form respect to a teacher, mentor, historical traditions, folk heroes, own traditions, holidays, ceremonies. The school did not pay enough attention to the education of such features as organization, accuracy, ability to plan their time, to produce punctuality and accuracy. The school should inculcate love to the work of people; more attention to the practical application of moral and religious values, the use of works of fiction, examples from life. The task of the teacher concerning the formation of positive features of character is described. The evaluation of war as an inhumane way of solving problems is given. The role of teachers and schools in upbringing the students in the post-war period is revealed.

Keywords: a war; an education; the pupils; a school; values of education; the formation of character; Ostap Makarushka.

$\Pi$ остановка проблеми. Сучасний прорив у сфері наукового осмислення війни як явища пов'язане 3 духовним оновленням українського суспільства, наданням гласності багатьом негативним явищам війни, які свідомо замовчувалися. Війна руйнує та нищить, приносить із собою страх, біль, страждання. Вона забирає тисячі та мільйони життів, з'являються 


\section{ОСТАП МАКАРУШКА ПРО ВПЛИВ ВІЙНИ НА ВИХОВАННЯ ДИТИНИ}

біженці, багато вдів та сиріт. Історія війн та збройних конфліктів спонукає замислитись про цінність кожного людського життя, яке не повинно стати розмінною монетою у геополітичних амбіціях жодної держави.

Сучасний матеріалізм все більше опанував суспільством, витіснивши на другий план такі риси молоді, як мужність, відданість, патріотизм, релігійність, відвертість, шляхетність, гідність, небайдужість, співчуття, ініціативність. Підсвідомість дитини так влаштована, що вона швидко копіює, змальовує відомі приклади для наслідування. Завдання педагога формування свідомої та відповідальної за себе та інших особистості у складному світі, сповненому конфліктів, криз та непорозуміння. У післявоєнний період діти дуже швидко ставали дорослими, на другий план відходили загальноприйняті критерії дорослості: фізичний розвиток, емоційна та соціальна зрілість.

Аналіз основних досліджень і публікацій. Війна завжди $\epsilon$ надзвичайно складним, суперечливим та трагічним явищем в історії людства, що викликає інтерес у політологів, істориків, соціологів, психологів та педагогів. Педагогічна наука у питаннях висвітлення війни повинна зламати стереотипи масової свідомості. Про події Першої світової війни та їх вплив на молодь писали О. Авдикович, К. Гриневич, О. Кобилянська, Я. Корчак, А. Макаренко, О. Макарушка, В. Стефаник, В. Сухомлинський, О. Турянський. На жаль, на шпальтах педагогічних часописів тема війни не знайшла поки що висвітлення.

Метою статі $є$ обгрунтування з педагогічної точки зору позитивного і негативного впливу війни на виховання дітей та молоді у педагогічній спадщині Остапа Макарушки (1867 - 1931).

Виклад основного матеріалу дослідження. Актуальною у першій третині XX ст. була тема впливу війни на виховання, проте й не втратив значення у реаліях сьогодення: військові події на Сході нашої країни впливають не тільки на молодь, а на все українське суспільство. Аналіз джерельної бази засвідчує, що проблема війни широко обговорювалася на сторінках педагогічних часописів першої третини XX ст. За дослідженням українського історика в еміграції І. Нагаєвського (1908 - 1989), лише в Галичині було розстріляно та повішено 36 тис. українських цивільних людей, у тому числі стариків і жінок; стільки ж українських в'язнів загинули в австрійських концтаборах $[5,58]$.

Широка дискусія щодо впливу війни у вчительському середовищі розгорнулась після
1917 р. Ніхто не суперечив тому, що війна $є$ справжнім лихом, проте життя ставило питання: “Як будувати життя після війни?”. Учительська спільнота, серед якої перебував О. Макарушка, обговорювала питання, ключовими ідеями яких були:

- війна виховує у молоді впевненість більшою мірою, ніж у мирний час;

- вплив війни на суспільство відчується згодом, коли їі учасники повернуться додому;

- прикро, що культура не облагороджує людей, не оберігає їх від жорстокості;

- школа повинна прищеплювати любов до праці людей;

- поганий приклад дають окремі вчителі, слова яких розходяться із ділом;

- педагогам у школі варто приділяти більше уваги практичному застосуванню моральнорелігійних цінностей;

- хибна думка переслідує військових, що вступ на військову службу звільняє від моральних приписів, а коли повертаються до своїх осель, то нові переконання переносяться на навколишніх $[3,17]$.

Як досвідчений педагог та психолог, О. Макарушка $\epsilon$ ініціатором дискусії у вчительському середовищі. Означеній проблемі він присвятив працю "Вплив війни на вихованє”, яка вийшла друком у 1917 р. Педагог звертає увагу педагогічної громадськості на розгляд, обговорення та глибокий аналіз усіх сторін військових дій, їх вплив на суспільство та молодь зокрема. В україномовній літературі представлено спогади, оповідання, картини, поезії, які, на його глибоке переконання, репрезентують зовнішню сторону війни, а не відображають іiї сутності, ï духу: "ніхто не подав нам ще описів психологічних процесів, спричинених війною, ані не вказав на потребу зміни поглядів, переконань і реформи у не одній справі загальної вартості" $[3,4]$.

Проаналізувавши соціально-педагогічні аспекти війни, О. Макарушка дійшов переконання, що війна формує у людей молодого віку такі риси: дисциплінованість, співчуття, справедливість, патріотизм, національну ідентичність, релігійність. Педагог вказує і на негативні наслідки війни: здичавіння, цинічну неповагу до чужої власності, приниження людської гідності, алкоголізм, грубе сексуальне насилля, наругу над релігійними святинями, осквернення релігійних приміщень й освячених місць [3, $15-16]$.

Особливого значення потребує питання впливу жорстокої військової дисципліни на молодь у 18- 
річному віці. У молоді потрібно виховувати точність, повагу до праці, уміння дотримуватися слова, негативне ставлення до шкідливих звичок, почуття обов' язку, вміння опанувати себе. Залізна рука військової дисципліни виховує залізні характери, а після закінчення війни може мати вельми благородний вплив на формування почуття обов'язку, пунктуальності, уміння опанувати себе та долати самолюбство [3, 4].

Молода людина має бути готовою безоглядно виконувати військовий послух, переносити кількаденний голод, нечувану спрагу, втому, безсоння, рани, каліцтва, операції, а, крім того, нестерпними можуть бути моральні муки: туга за сім’€ю, турбота про родичів, жінок, дітей, смуток за полеглими товаришами-побратимами. Молодий дух має сформуватися не тільки у шкільному оточені, але й молодіжно-спортивних товариствах “Сокіл”, “Пласт”. Їхню діяльність педагог високо оцінював у передвоєний період, “коли товариства і стрілецькі дружини зуміють сформувати у молоду дух благородної карності, послуху і почуття громадянської єдності" $[3,5]$.

О. Макарушка із сумом констатує факти, на які тогочасна школа не звертала належної уваги. Зокрема йдеться про виховання таких рис, як організованість, точність, вміння спланувати свій час, вироблення пунктуальності та точності. Згодом молоді люди, не привчені до організованої поведінки у школі, переносять такі негативні моменти у доросле життя. Свідченням цього $\epsilon$ неточний початок, зазвичай на годину пізніше, засідань, зборів, лекцій, театральних вистав, Навіть часописи громадськість отримує із запізненням (не о сьомій годині, а значно пізніше), що є однією з причин обурення населення, нівелювання україномовною пресою $[3,6]$.

Наочним та глибоко яскравим прикладом пунктуальності та організованості для молоді $\epsilon$ сама особистість педагога, наставника. На думку О. Макарушки, педагог є духовно вищим тільки тоді, коли надихає молоде покоління своє постаттю, поведінкою, діяльністю. Педагог, катехит, вчитель математики чи вчитель руханки вчить карності передовсім замилуванням i пошаною до свого предмету, а згодом загалом своєю поведінкою $[3,8]$.

Формувати повагу в учнів потрібно не тільки до вчителя, наставника, але й історичних традицій, народних героїв, власних традицій, свят, обрядів. Там, де немає послуху, там - анархія. Послух неможливо демонструвати зовні, оскільки він - наслідок усіх моральних педагогічних впливів. Усвідомлення і теоретичне навчання також тут не допоможе, тому вимогою до учителів $\epsilon$ організація та проведення для молоді лекцій та бесід про карність [3, 9].

Завданням педагогіки є виховання невтомних i працелюбних робітників, що потребує системної, цілеспрямованої роботи учителя над такою психологічно рисою, як самостійність. Саме від педагога залежить: категоричність поставлених завдань, яскравість наочних прикладів, мотиваційні поетапні дії у формуванні самостійності. О. Макарушка вважає за доцільне використовувати метод прикладу у вихованні молоді. Учитель може навести приклад героїчних вчинків солдатів на фронті. Продовжуючи роботу над формуванням характеру, педагог описує такі дії: у цьому контексті відважуюся поставити категоричну вимогу, щоб школа вимагала від молоді більше духовної праці, а то й напруження, ніж до цього часу. Це причиниться до вироблення самостійності, усуне марнування часу, виробить почуття духовної сили, розбудить замилування до предмету, навчить шанувати свою й чужу працю, зробить молодих людей поважнішими - одним словом, покладе основу до розуміння та поціновування карності $[3,10]$.

Особливу увагу у висвітленні питання впливу війни на виховання потрібно звернути на християнське буття людини. На початку XX ст. роль церкви у духовному вихованні нації була провідною. Мова не йшла про конкретну релігію чи конфесію, а про пояснення дитині основ християнського буття, внутрішнього зв'язку з Богом, понять, що стосуються безсмертя людської душі, правил людяності, християнської любові, толерантності, співчуття до ближнього. О. Макарушка підкреслював, що не тільки ті, що стоять на фронті перед загрозою смерті, не тільки хворі та немічні, не тільки осиротілі родини, але майже ціле людство знаходить у вірі і в Свангелію розраду, заспокоєння, любов до ближнього. I тільки під час війни людство пригадало собі християнську науку любові, а катехити мають тепер найкращу нагоду утвердити молодь на все життя у Христовій вірі і любові до ближнього $[3,14]$.

На молоду, ще не сформовану людину, безжалісно впливає ненависть, брехня, при цьому руйнуються основи християнської віри та людської етики. Солдату підступно стараються насадити політичні, релігійні чи соціальні доктрини, часто ним незрозумілі в силу відсутнього життєвого досвіду, не достатнього рівня освіченості. При таких життєвих обставинах ніхто не наголошує, що війна може бути виправдана лише в одному випадку, якщо вона національно-визвольна. Війна у молодих людей великою мірою виховує почуття релігійності, у 


\section{ОСТАП МАКАРУШКА ПРО ВПЛИВ ВІЙНИ НА ВИХОВАННЯ ДИТИНИ}

кого воно було, ще більше загостює релігійні поривання. Спрацювує психологічний момент у житті солдата на полі бою, який стоїть перед загрозою смерті, звертається та знаходить розраду у Христовій вірі та Святім Свангелії, саме у словах апостола Павла до римлян: “Не дозволь, щоб зло тебе перемогло, але перемагай зло добром” (Рим. 12, 21) [6, 187].

До війни більшість учнів виховуються у традиційних ідеалах мрійності, романтизму та платонічної любові сильніших народів до слабших. Політичні реалії є зовсім іншими, історія співжиття із “сильнішим народом” сповнена трагічних сторін. Як наслідок - слабший народ залишається позаду могутніх союзників.

Однією зі сторін війни є усвідомлення власної національної ідеології, формування почуття національної гідності. 3 поглядами О. Макарушки погоджується сучасний київський дослідник А. Каушнян. Він пише: "Перша світова війна вивела на перший план питання національного усвідомлення. Саме вступаючи на теренах бою, селяни усвідомлювали, що для них $\epsilon$ батьківщиною. Воюючи по обидва боки фронту, вони говорили, співали українською мовою, мали схожі традиції. Усвідомлення цього факту мало величезне значення для національної самоідентифікації українських солдат. Адже, як відомо, серед численних самовизначень особистості чільне місце завжди відводиться саме національній ідентифікації, що у розвиненому вигляді постає як національна самосвідомість [2,77].

Негативний вплив війна справляє на людей старшого віку, які у міру сформованості поглядів оцінюють нелегку та складну боротьбу з ворогом. Адже війни ніколи не приносять позитиву, зростає агресія та насильство у суспільстві. Війна належить до тих соціальних катаклізмів, що призводять до непоправних наслідків у всіх сферах суспільного життя. Значних демографічних втрат зазнала українська наука. 3 цього приводу сучасник педагога Р. Ілевич відзначає: “Українська наука, котра перед війною як найкраще розвивала ся та не дійшла була до свого розквіту, потерпіла чимало втрат у часи воєнної хуртовини. Не лише що не стало не одного 3 піонерів нашого наукового письменства, але також загинуло на полях битви багато нашого молодого покоління" $[1,21]$.

О. Макарушка акцентує увагу на психологічних моментах виховання та навчання під час війни: “вчителі не звертаються до педагогічної літератури чи художніх творів, у суспільстві панує загальна апатія, ніхто не надає найменшої ваги, що раз більше у цьому переконуюсь і то не раз, що літературні твори, то продукт напруженої духовної праці, а для учителя $\epsilon$ важким примусовим тягарем” $[3,12]$. Прихована проблема війни у тому, що формується нове покоління, виховане на цінностях, які актуальними є для військового часу. Війна популяризує агресію, насильницькі методи розв'язання проблем, вона дискредитує норми моралі, норми права, діалог та компроміс як засіб досягнення цілей.

Грунтовно оцінивши стан освіти та умови розвитку виробництва на початку XX століття, О. Макарушка зумів передбачити формування у суспільстві матеріалістичного позитивізму, а саме зіставляння реальних вимог технічного прогресу потребами сучасної школи. Адже саме наука повинна кардинально змінити світогляд та знайти практичне застосування. Після війни, на його думку, у суспільному житті з'явився матеріалістичний позитивізм. I хоча старшим людям, вихованим на ідеалістичних засадах, $€$ ніяково, “до сього нового суспільного напрямку приставати, вони все таки, охоплені могутньою хвилею, мусять плисти 3 ним. Інакше нове життя піде поверх них або викине їх за борт” $[4,2]$.

Вплив війни є значущим фактором на самих учасників бойових дій, пробуджує у них співчуття до поранених, до тих хто, у шпиталях, у домах інвалідів. Педагог на військових прикладах має формувати в учнів почуття милосердя, співчуття, співпереживання, чутливість, добросердечність. Завдяки милосердним людям ми віримо в торжество справедливості, перемогу над злом. Важливо, що милосердя стало не просто словом, а рисою характеру кожної молодої людини. Завдання вчителя наводити приклади милосердя, один із багатьох, це життя та діяльність матері Терези, яка народилась у 1910 р. в Албанії, проте фактично все життя прожила в Індії, де заснувала добродійну організації“Орден милосердя”. У 1979 році удостоєна Нобелівської премії Миру. Адже по-справжньому милосердна людина не може змінювати відповідно обставин, бо це не поведінка, а стан душі, риса, яка виховується 3 дитинства. Зрозумівши один раз, що таке милосердя, зробивши перші милосердні вчинки, людина вже не зміниться до кінця життя. Педагогам варто взяти до уваги те, що маленький світ дитини складається із найпростішого і найсуттєвішого, у якому дитина почувається просто людиною, без ідеологічних нашарувань та спотворень, які несе війна.

Висновки. Війни та військові конфлікти спричиняють переоцінку цінностей. 3 неймовірою швидкістю відбувається дегуманізація людини, 
коли їй відмовляють у праві бути людиною. У такі моменти люди різного віку, а також діти піддаються стресовим розладам, таким як запаморочення, тривога, нерозуміння, погіршення пам'яті, втрата концентрації, нерозуміння подій, що відбуваються навколо. Діти швидко дорослішають. Проте є позитивні наслідки війни: вона виховує дисципліну, підвищуються та загострюються релігійні почуття, проходить процес усвідомлення національної ідентичності. Отже, війна - це антигуманний спосіб розв'язання проблем, вона виявляє найслабші сторони школи. У нашому складному світі, сповненому конфліктів, криз та непорозумінь, кожний новий набутий досвід дає можливість інтегрувати у своє нове життя.

\section{ЛІТЕРАТУРА}

1. Ілевич Р. Задачі нашого наукового письменства в теперішню пору / Р. Ілевич // Наша школа. - 1918. - Р. ІХ. - Зш. 3-4. - С. 21 - 24.

2. Каушнян А. Модернізація українського народу під впливом війни: історія і сучасність / А. Каушнян // Великі війни, великі трансформації: історична соціологія 20-го століття, 1914 - 2014: Матеріали міжнародної наук.-практ. конф. (м. Київ, 27 - 28 листопада 2014 р.) / Уклад. А.А. Мельниченко, П.В. Кутуєв, А.О. Мігалуш. - К.: Політехніка, 2014. - С. 75 - 77.

3. Макарушка О. Вплив війни на вихованє / О. Макарушка. - Львів: Друк. Наукового Товариста ім. Шевченка. - 1917. - 20 с.

4. Макарушка О. Потреби хвилі/О. Макарушка // Українська Школа. - 1928. - Р. ХІІІ. - Ч. 1. C. $1-3$.

5. Нагаєвський 1. Історія Української держави
XX століття / I. Нагаєвський. - К.: Український письменник, 1994. - 412 с.

6. Святе письмо. - Рим: Вид-во отців Василіан "Мiсіонер", 2007.- 350 c.

\section{REFERENCES}

1. Ilevich, R. (1918). Zadachi nashoho naukovoho pysmenstva $\mathrm{v}$ teperishniu poru [The Problems of Our Scientific Writing in the Present Period]. Our School, R. IX, Zsh 3-4, pp. 21 - 24.[in Ukrainian].

2. Kaushnyan, A. (2014). Modernizatsiia ukrainskoho narodu pid vplyvom viiny: istoriia $i$ suchasnist [Modernization of the Ukrainian people under the influence of war: history and modernity]. Velyki viiny, velyki transformatsii: istorychna sotsiolohiia 20-ho stolittia, 1914-2014: Materialy mizhnarodnoi nauk.-prakt. konf. (m. Kyiv, 27-28 lystopada 2014 r.) - Great Wars, Great Transformations: Historical Sociology of the 20th Century, 1914-2014: Proceedings of the International Scientific Conference (pp.70 - 81). (Kyiv, November 27-28, 2014). (Eds.). A.A. Melnichenko, P.V. Kutuyev, A.O. Migalush. Kyiv: Politechnika.[in Ukrainian].

3. Macarushka, O. (1917). Vplyv viiny na vykhovanie [The Influence of the War on the Nurse]. Lviv: Print. Scientific Comrade to them. Shevchenko, 20 p. [in Ukrainian].

4. Makarushka, O. (1928). Potreby khvyli [Wave Needs]. Ukrainian School, R. XIII, Part 1, pp. 1 3. [in Ukrainian].

5. Nagaevsky, I. (1994). Istoriia Ukrainskoi derzhavy XX stolittia [History of the Ukrainian state of the XX century]. Kyiv: Ukrainian writer, 412 p.[in Ukrainian].

6. Sviate pysmo (2007). [Sainted Letter]. Rome: View of Fathers Vasilian "Missionary", 350 p. [in Ukrainian].

Стаття надійшла до редакції 02.03.2018

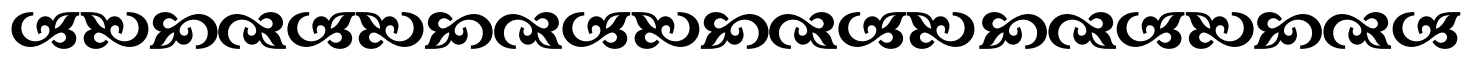

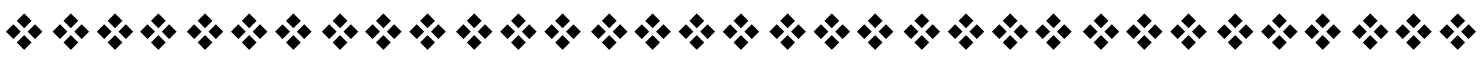

“Від правильного виховання дітей залежить добробут усвого народу". Dжон Яок
англійсьжий білособ

"Лриниип мистеитва виховання говорить: діти повинні виховуватися не для съогодення, а для майбутнъого, можливо қращого стану роду людського! ” 